\title{
Stab Avulsion up to Date
}

\author{
山本崇
}

\begin{abstract}
要 約：下肢静脈瘤の手術の中で分枝静脈瘤へのstab avulsionは, 単に整容的な満足度を高めるための ものではなく, 症状の改善に貢献し, 追加治療の必要性および再発率の軽減に繋がる術式である。その手順 を詳説する．まず対象となる血管の周囲に， $0.1 \%$ リドカイン溶液を中心とした溶液を大量に浸潤させて局所 麻酔を行い，18G 注射針もしくはメスを用いて $2 \mathrm{~mm}$ 程度の穿刺孔を設ける. 穿刺孔よりフックを挿入し，皮 膚に置いた対側の手指との間で挟むようにして対象となる血管を同定し，銁に引つ掛けて穿刺孔より引き出 す．引き出された血管を鉗子で把持し，血管の走行や枝分かれを確認した後，血管周囲の組織を動かすこと により血管を剥離し，摘出する，合併症は出血・神経障害・感染などで，注意して行う限りはいずれも軽度 なものである.
\end{abstract}

○索引用語：下肢静脈瘤, stab avulsion, 静脈切除術

静脈学 2017; 28(3): 329-335

はじめに

下肢静脈瘤血管内焼灼術を行う際に，分枝静脈瘤の 処置を同時に行うべきか, 待機的にその要否を判断する べきかという議論は以前よりなされており，いくつかの 研究が行われている。例えば，伏在静脈の焼灼術だけ行 い分枝静脈瘤を放置した場合， $40 ６ 0 \%$ 程度の症例で 数力月以内に何らかの追加治療を必要としたと報告され ている ${ }^{1,2)}$ 。また, Carradice, El-Sheikhaらは伏在静脈の 燒灼術にstab avulsion（以下SA）を併施した群と燒灼術 だけを行った群の 5 年までの成績を比較して，SAを併 施した群が自覚症状の改善度において有意に優れ, 再発 などで追加治療を要する例が有意に少なかったと報告し ている ${ }^{3,4)}$ ，さらに, Pittalugaらは伏在静脈治療を行わ ず分枝静脈㽣へのSAのみを行った症例を 5 年間観察し, 再治療率・再発率に関して非常に優れた成績を報告して いる ${ }^{5)}$. SAを単に整容的に優れた結果を出すための手

お茶の水血管外科クリニック

受付：2017年9月20日受理：2017年9月22日

doi: 10.7134/phlebol.17-19

\section{(cc) BY-NC-ND}

技と誤解している方も多いが，上に示したようにSAは 追加治療や再発の可能性を下げることで下肢静脈瘤に伴 う医療コスト・社会コストの低減を得ることを可能とし た手技であり，仮に術後に醜い瘏痕か残ったとしても血 流の上では行う意義は十分にある，たた，醜形を残す と術者・患者ともに満足度が低くなることから，できる だけ『美しく』治すほうが望ましいというのが実状であ り，本稿がわずかでもその役に立てればと願う。

\section{適応}

下肢静脈瘤に関与する血管は，解剖学的に伏在静脈 と分枝静脈，そして穿通枝と 3 種類に分類できる. SA はその中でも分枝静脈に特化した治療法となり，通常の 下肢静脈瘤手術では伏在静脈への血管内焼灼術や静脈抜 去術と分枝静脈へのSAが組み合わせて行われる例が多 い.

SAの技術的な適応は広く, 分枝静脈であれば静脈抜 去術後の再発例や陰部静脈瘤なども含めて, さまざまな 形態の静脈瘤に対応することができる，とくに伏在静脈 抜去（結紮）術後の再発例などは良い適応となる。逆 に，分枝静脈でも過去に硬化療法を受けていたり，血栓 性静脈炎の既往があったり，脂肪皮膚硬化症を伴ってい 
たりと周囲組織への癒着が強い症例では治療に難渋する 症例を認める。

SAは非常に低侵襲な手技であるため,「下肢静脈瘤に 対する血管内治療のガイドライン」王の条件を満たし治 療適応となった症例の中で, SAが適さない例はごくわ ずかである。例えばわれわれの施設で伏在静脈への焼灼 術を行う際に，SAを行わなかった頻度は6〜10\%程度 であり，その理由として抗血栓薬が休止できない例や肝 不全などで止血能が低下している例，患者自身が分枝静 脈への処置を希望しなかった例などが挙げられる.

\section{手技}

SAの術式を, 治療の中で実際に行われる順番に詳説 する.

\section{準備}

SAで使用される物品は少なく, 麻酔に用いるリドカ イン溶液・針，穿刺に用いる針もしくはメス，血管を 引つ掛けるためのフック，血管を引っ張るための鉗子が 4〜5本，ハサミが必要となる。

\section{デザイン}

必ず，手術前に立位もしくは端座位で手術計画を確 認する。 まず，超音波装置にて伏在静脈・深部静脈・穿 通枝の状態を確認し，その情報も踏まえて分枝静脈の走 行・枝分かれを目視・触診によって調べ, 油性ペンを用 いて皮膚に記載する，超音波装置で観察すると，脂肪組 織は薄い膜によって浅層と深層に分かれていることがわ かる。，一般的には伏在静脈やその主要分枝は脂肪深層を 走行し, それらは弁不全を生じていても蛇行・屈曲する ことはほとんどない，それに対し，脂肪浅層を走行する 無名の静脈は屈曲・蛇行しており静脈瘤として視認され る. SAでは原則的に脂肪浅層を走行する血管を対象と する，後述するが，深層の血管をフックで探査すること はあまり望ましくなく, 深層の血管を取る場合はやや工 夫を要する。 そして, 伏在静脈が部分的に浅層を走行す る症例も多く見られるが，そういった症例では浅層を走 行する部位はSAの対象としている（Fig. 1)。デザイン を記載した後に患者自身にも確認してもらいながら，治 療を希望する部位や切除が困難な部位に関して最終的な 説明を行うことで，治療希望部位に関するトラブルの大 半は避けることができる，後述するように麻酔液の注入 後に血管の位置が多少ずれる例が多いため, 精密なデザ インを行うことに疑問を感じることもあるが, デザイン はSAで取る血管に印を付けているだけではなく，患肢 の全体像も把握するために重要な作業であり決しておろ

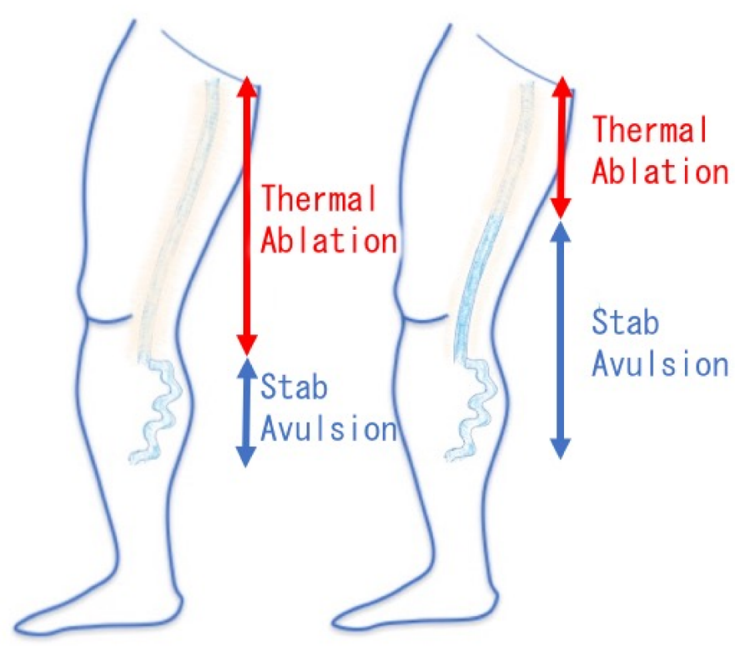

Fig. 1 Superficial part of GSVs are usually the target of stab avulsion. そかにしてはいけない。

\section{麻酔}

麻酔に用いる道具：SAを予定する部位にTumescent Local Anesthesia（以下TLA）とよばれる局所浸潤麻酔 を行う。TLA液の組成は生理食塩水 $430 \mathrm{~mL}$ に 10 万倍 エピネフリン添加 $1 \%$ リドカインを $50 \mathrm{~mL}, 7 \%$ 炭酸水素 ナトリウム $20 \mathrm{~mL}$ を添加したものを使用しており, リド カイン濃度を $1000 \mathrm{mg} / \mathrm{L}(0.1 \%)$ と薄くすることで大量 の溶液を安全に使用することができる7)。通常，片足の 大伏在静脈焼灼術に要する TLA 液は伏在静脈に200 $300 \mathrm{~mL}$ 程度, $\mathrm{SA}$ に 100 $300 \mathrm{~mL}$ 程度である.リドカイ ンの安全な使用量の上限については諸説あり, 最近の報 告では $25 \mathrm{mg} / \mathrm{kg}$ 程度とされている ${ }^{8)}$ (体重 $50 \mathrm{~kg}$ なら上 記組成で $1250 \mathrm{~mL}$ に相当する)，さらに，上記組成では リドカイン濃度が $1000 \mathrm{mg} / \mathrm{L}$ とっているが, $400 \mathrm{mg} / \mathrm{L}$ 程度に希釈しても同等の鎮痛効果が得られるとも報告さ れている ${ }^{9)}$. TLA麻酔注射の役割は鎮痛・止血・剥離と 3つあり，もち万ん鎮痛効果が最も重要ではあるが，工 ピネフリンによる止血効果や, 血管周囲の剝離効果も欠

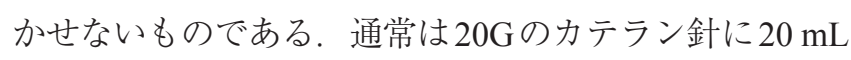
のシリンジを接続して注入する。針の太さやシリンジの 大きさにはさまざまな選択肢があり，術者によって好み は別れると思われるが筆者の経験上は上記組み合わせが 最良であった，TLA液注入用のポンプを使える場合は， 注入が大幅に快適になるので使用することを招すすめす る. 他にも TLA 液を冷却することで注入時や術後の痛 みを有意に軽隇することができる ${ }^{10)}$ と報告されている.

TLA液の注射範囲：SAの対象となる静脈は原則的に 浅層を走行するが，実際の手術では分枝静脈に繋がる 深層の静脈も処理する必要があり，TLA液は浅層・深 


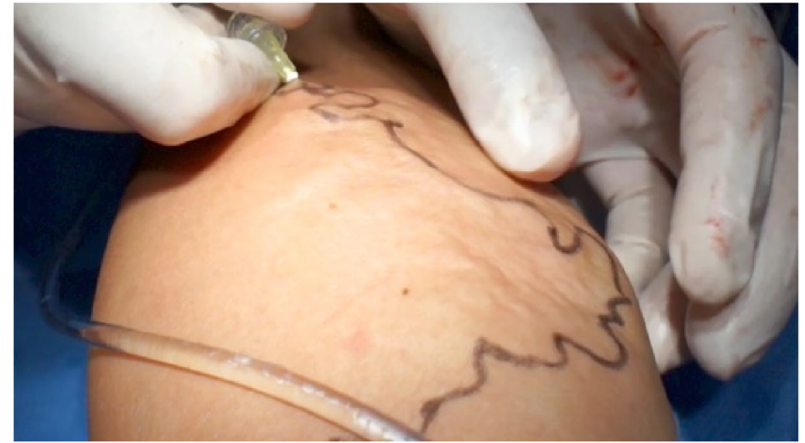

Fig. 2 The skin tend to become uneven when the tumescent fluid is infused into the superficial layer of subdermal fat.

層の両方に注入する。そして，TLA液がどちらの層に 入っているのか見分けることは簡単で，超音波装置を 使用すれば針の位置や液の広がりが確認でき，また超音 波装置を使わなくても皮膚面の凹凸を観察することで TLA 液の深さは判別できる。TLA液が深層に入ると全 体に膨満し腫脹するが皮膚面は平坦で柔らかく, 浅層に 入ると皮膚面は境界明瞭に膨隆し，皮膚と筋膜とを繋ぐ 纎維組織の付着部で皮膚が凹むことによりミカンの皮の ような外見となる（Fig. 2)。さらには，TLA液が血管 周囲に入ると血管に沿って $10 \mathrm{~cm}$ 程度先までTLA液が 進行することがあり，そういった場合にはその血管は注 射によって剥離されており簡単に引き出すことが可能で ある。また，針を進める際には必ずTLA液を注入しな がら行うことで，針の血管内への誤進入を防ぐことがで きる。

他の麻酔との併用：TLA と全身麻酔や腰椎麻酔, 静 脈麻酔などが併用されていることが多い，麻酔法につい ては各術者が置かれている環境に最も適したものを選択 すれば良いと思われるが，もし静脈瘤の治療だけを考慮 して選択するなら TLAのみもしくはTLAに軽い静脈麻 酔の組み合わせが望ましい，筆者はTLAに少量の静脈 麻酔を加えて手術を行っているが，手術の最初に投与す る静脈麻酔薬はTLA注入時の苦痛を和らげる程度にし か効いておらず，SAを行うころにはほとんどの例で覚 醒している，TLAが効いているため原則的には痛みな くSAを行うことができ，もしある程度以上の神経に触 れた場合は痛みを訴える。これが非常に重要で，痛みを 訴えた際に速やかに手技を中止すれば，後日まで神経障 害が残ることはほとんどない，SAでは皮下の静脈を盲 目的に探索する必要があり，静脈と感触が似た神経を 引っ掛けてしまう危険性がある。最小限の麻酔で治療を 行うことによりその神経障害のリスクがかなり低減でき ると考えられる。

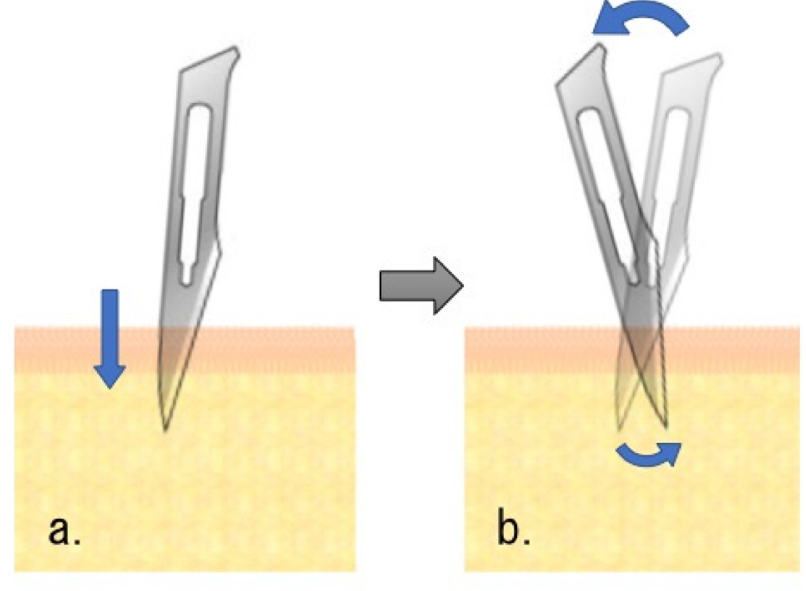

Fig. 3 The usage of No.11 scalpel.

穿刺

穿刺孔の大きさ：十分に麻酔を行った後に皮膚を穿 刺し，生じた穿刺孔から血管をフックで掛けて引っ張 り出す, その操作の中で最も創に負担がかかるのは血管 を引っ張り出す際である。穿刺孔の長さは当然ながら 短いほうが患者には好まれる。ただし，他の手術と同 様に創が短くなればなるほど作業は困難になり，例え ば1.5 mm以下ではフックさえスムーズには入らず，無 理に太い血管を引っ張り出すと創縁に負担がかかりひど い時には創縁が裂けることもある。逆に穿刺孔を長くす ると作業はとても簡単になるものの，後に残る瘏痕は視 認されやすくなり， $3 \mathrm{~mm}$ 以上では明らかに認識される. したがって，創の長さは作業が問題なく行える範囲での 最短のものが理想で，具体的には $1.5 \sim 2.5 \mathrm{~mm}$ 程度にな る.

使用する道具：穿刺に用いる道具は注射針もしくは メスのどちらかとなる，注射針は $18 \mathrm{G}$ 夲ちうど良い 大きさで，価格が安いため容易に導入することができ る。深く刺しても創の大きさがだいたい $2 \mathrm{~mm}$ と変わら ないため刺すときに細かな注意は必要ないが，刃の形 状が円弧状であるため創も円弧状になるのが欠点であ る、メスを使用する場合はNo.11 メスが比較的使用しや すい，值段も高くなく，容易に直線状の創が得られる. ただ，刃の幅が先端より徐々に太くなるため，深く刺し すぎると当然ながら創は長くなり，また外面の創より内 面の創が短くなる傾向があることから，穿刺の際には 外面を支点として先端をできるだけ大きく動かし，“刺 す”というよりは内面を切るような動作が必要となる (Fig. 3)．注射針と No. 11 メ久両者の長所を併せもつよ うな道具が眼科用メスである。眼科用メスとして, 複数 の会社よりさまざまな形状・大きさのメスが販売されて 


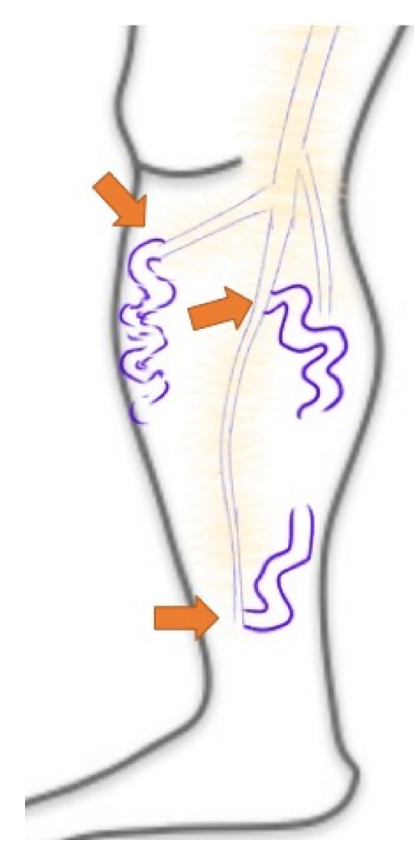

Fig. 4 The junctions between tributaries and veins in the deeper fat layer are the ideal regions to start the stab avulsion.

おり, その中でも $1.5 \sim 1.7 \mathrm{~mm}$ 程度の直線状の刃を備え たものはSAの穿刺では最良の選択肢となる。価格がや や高いことだけが難点である。

位置：穿刺の最優先な位置は分岐部，とくに伏在静脈 などの深層を走行する血管との分岐部である，深層を走 行する血管は浅層のものより丈夫で, 直視下で直接に把 持して結紮（もしくは抜去）処理する必要があり，離れ た創から盲目的に操作できるものではない.したがっ て，とくに深層を走行する血管との分岐部から処理を始 めることをすすめる（Fig. 4)，それ以外の穿刺位置に関 してはあまりこだわる必要はないと考えている。理由 は，もし誤った部位を穿刺しそこから血管が取れなかっ たとしても，丁寧な作業を心がけていればその創はほと んど目立たずに治癒するからだ，穿刺し 30 秒程度探し ても血管が見つからない場合は，速やかに次の穿刺を行 うほうが結果は良い，そして，どこを穿刺すれは確実に 血管が見つかるかという疑問に対する簡単な答えはな い.デザインを丁寧に行っていても TLAによって想像 以上に血管の太さ・長さは縮小しており, 結果的にもと のデザインと異なるところに走行していることはよく経 験する。したがって，あえて言うなら最も確実な穿刺位 置は引き出した血管を引っ張ったときに凹むところであ る，その他，血管が太ければ触診によって凹む場所を穿 刺すれば良い，作業を進める方向に関しては，中枢から と末梢からの2つの選択肢がある，血管を繋げて引き抜 く際に創縁に与えるダメージを最小にするためには，血 a.

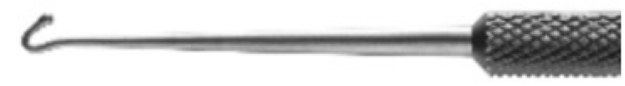

b.

C.

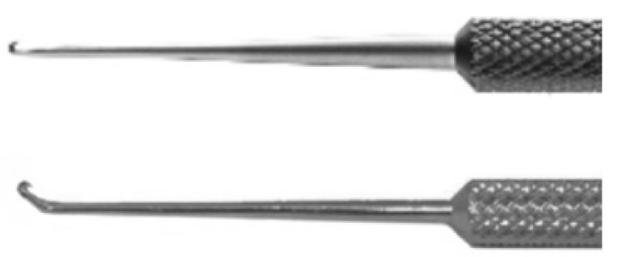

Fig. 5 Shapes of hooks. a.: A hook with a ball at the tip of the hook. b.: A hook with straight neck. c.: A hook with bended neck.

管が細い末梢から作業するほうが望ましい，ただ，実際 にSAを行うと想定外に血管が細かったり癒着していた り弱かったりと，さまざまな理由で末梢側の治療を断念 することがあり，中枢から治療するほうが効率が良いの は間違いない.

フック

フックの選択 : フックは数多くの種類が販売されて おり，各自が自分の好みに合うものを使用されるのが良 いと思われるが，ここでは筆者の選択基準を挙げる。 ま ず，フックの種類によって先端の形状・角度, 素材など が異なる（Fig. 5)。先端は鋭く尖ったものと, 逆に球状 のものを取り付けることで鈍的にしたものが存在する. 球を付ける目的は, 先端で血管を損傷することを避け, より安全に引っ張りたいという意図だと思われるが, 血 管を引つ掛けた球が通過するためには穿刺孔を大きくす る必要があり, 結果的に術後の創が目立つ傾向がある ため筆者は使用していない，また，フックの先端は血管 を引っ掛けるためにガイドワイヤーで言うと「J」型に 曲げられて抢り，そのネックに当たる部分が直線状のも のと 30〜 45程度屈曲したものがある，ネックの形が異 なると血管を引っ掛ける際の手の動きは全く違うものに なり, どちらが優れているというものではないが術者に よっては相性が最も顕著になる部分である。最後に, 意 外と使用感に大きな影響を与えるのが材質である。一般 的なフックはステンレスで作られているが, チタンのも のは材質がより軽くて硬くて強いことから，ステンレス より細くしなりが少なくなり，血管を探す際により鋭敏 な感触をもたらしてくれる。

フックの使い方：フックの役割は見えない血管を 引っ掛け, 穿刺孔まで引っ張り出すことである. フック は先端の尖ったほうが皮膚面を向くように血管の下に差 し入れ，反対の手指とフックの間で血管を挟み込むよう なイメージで動かし（Fig. 6)，血管が見つからない場合 は穿刺孔の周囲を方向を変えながら同じょうに探索す 


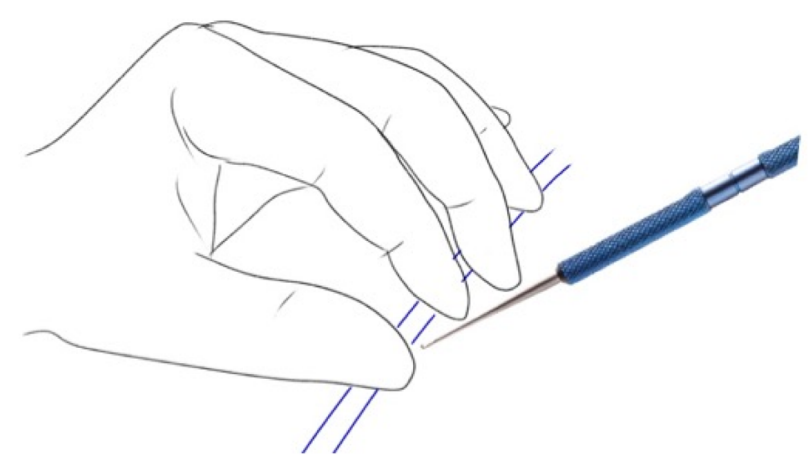

Fig. 6 The targeted vein is hooked between the point of the hook and the fingers of the contralateral hand.

る，血管と思われるものが引っ掛かれば，フックは動か さず反対の手指で周囲の組織を動かすことによって, 血 管を周囲より剝離する，そうすると，血管を破ることな く穿刺孔まで引っ張ることができる.フックを用いるの は血管の一部を鉗子にて安定して把持できるまでで, 鉗 子が使えるようになればそれ以上フックを使用するべき ではない，血管が見つからない場合も，フックを挿入す る長さは $1 \mathrm{~cm}$ 程度にとどめる。 それ以上遠くで血管が 引っ掛かったとしても穿刺孔まで引っ張り出すことは困 難だからだ。また，浅いところで血管が見つからなけれ ば深いところを探索したくなる気持ちは理解できるが, 深いところを探索すると神経障害の頻度・程度が増し, またうまく血管が引っかかったとしても反対の手指が使 いにくいため穿刺孔まで引っ張ることが困難となるた め，あまり掞すすめしない，繰り返すが，血管が見つか らない場合はその穿刺孔に固執するよりも速やかに次の 穿刺を行ったほうが結果は良い.

被膜の処理：注意を要するのが分枝を包んでいる被 膜が厚い症例である。分枝の周囲には持続的な炎症が伴 われるため, 炎症反応によって生じた㓔痕性組織が血管 の周囲を取り巻いている. 皮膚炎を伴った例や病恼期間 の長い高齢者ではしばしばその被膜が厚い例が存在し, 血管は被膜によって周囲組織と癒着しており可動性や柔 軟性がそしくなっている，ある程度慣れた術者でも血管 の感触が非常にわかりにくく，また血管を引つ張るとす ぐにちぎれてしまい難渋することが多い，そういった例 では先に被膜だけを引っ掛けて鋭的に切ってしまうこと で，血管を直接触れることができるようになり作業が容 易になることがある。

\section{血管処理}

用いる道具：モスキート鉗子を使用する．特別な道 具ではないが，筆者の選択基準を挙げると，まずは先端 がしっかりと噛み合っていること, そして先端が細めで

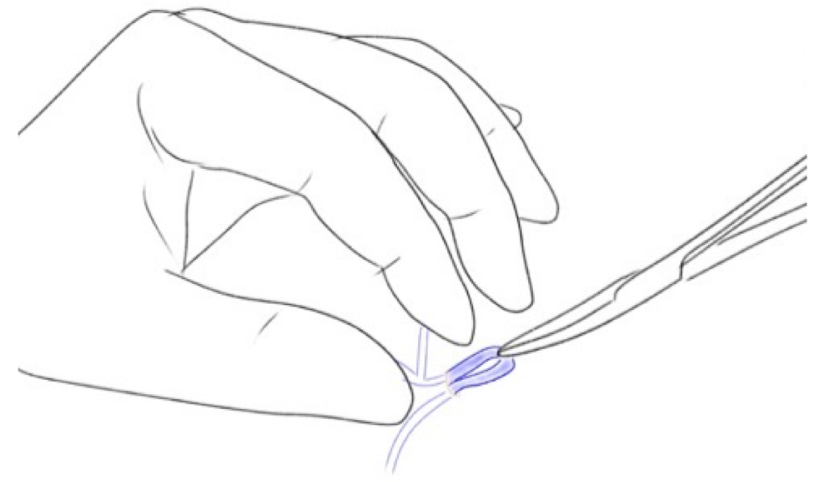

Fig. 7 The branches of the targeted vein are palpable when the vein is pulled.

あることが必須と考えている．鉗子の先端をよく見る と, 先端の長さが 2 本でやや異なるものや, 内側に切ら れた溝の形態が先端だけあっていないものが散見され る。そのような状態でも一般的な手術では問題になるこ とは少ないと思われるが, この治療ではモスキートの先 端を用いて血管を把持することがあり，先端の形態だけ はよく確認するべきである。

血管の牽引：最初に穿刺孔よりわずかに顔を出した 血管の一部を鉗子で把持するが，先端だけで把持してい る鉗子は外れやすいので, 優しく鉗子を動かして血管 がループ状に露出するまでゆっくりと劧引する。ルー プ状になればその一端を把持し，対側の指を周囲にお いた状態で軽く血管を牽引し，血管の方向を確認する (Fig. 7). 万向がわかれば，鉗子をその反対方向にやや 力を入れて引っ張り, テンションの加わった血管の周囲 を対側の指で剥離する，血管にはある程度の伸展性があ り, 本来の長さの $130 \%$ くらいまではバネのように加え た力に応じて伸長する，ただ，ある一定の長さに達する とそれ以上は一切伸びずに，切れてしまう．SAで血管 を引つ張る際にはその血管の弾力を感じることのできる 程度の力加減を維持することが重要で, 決して力任せに 行う作業ではない，とくにSAで取り出す血管は屈曲し ているうえに周囲と癒着しているため力加減は非常にわ かりにくいが，一定の力を維持しながら剝離している と，複雑に見えていた血管が糸をほぐすように杽引でき る、そしてある程度牽引すると, 血管の弾力がなくなり それ以上は伸びなくなる。伸びない理由は先での癒着が 激しいか，枝分かれがあるかのどちらかで，そこがその 穿刺孔から処理できる限界と考え，枝分かれの位置に新 たな穿刺孔を設けるべきである。

枝分かれの処理：牽引する血管の周囲をしっかりと 触れていると, 枝分かれが存在する部位は明白である. 
その枝分かれの処理には3つの方法がある。まずは結紮 処理で，枝分かれの部位に新たな穿刺孔を設け，直視下 に結紮切離する，枝分かれがある程度太い場合や末梢側 に存在する場合など出血する可能性の高い枝に行う，次 に鋭的切断処理がある。露出した枝分かれが細い場合に は，結紮を行わず，血管を鋭的に切ってしまってもほと んど出血することはない，最後に鈍的切断処理が挙げら れる，枝分かれの血管を露出することなく，体表面よ り枝分かれだけを強く押さえることで鈍的に切断できる ことがある．穿刺孔の数を減らすことができるので便利 ではあるが，枝分かれが弁不全を伴わない正常な血管で ある場合は，たとえその血管が細くても下肢静脈瘤で屈 曲蛇行した分枝よりは丈夫であることが多く，むやみに 引っ張ると取りたい血管のほうがちぎれてしまうため注 意が必要となる。

\section{合併症}

SAに伴われる合併症は実は非常に少なく, 関連が疑 われるものは出血, 神経障害, 血栓性静脈炎と感染くら いである。

出血：SA後に出血を生じる原因の多くを占めるのが, 『不十分な SA』である。しばしば，皮膚炎を伴い血管の 癒着が激しい例や，血管が非常にもろく簡単に破れてし まう例を認める，また，SAと称して血管を数力所で引 きちぎっている術者も見かける，そのようにして残さ れた血管はGSV末梢側や不全分枝などの流入路からの 出血源となる。幸い, 前述のような SAに適さない症例 は術前もしくは術中にすぐに判別できるので，そういっ た例では無理をせず確実に結紮できる程度の切除にとど めるほうが望ましい，ただし，適切なTLAの注射や術 後の圧迫が行われていれば，術中に取れてくる血管の太 さからイメージされるような出血をきたすことは稀であ る.

神経障害：麻酔を深くせず，フックによる探索を脂肪 浅層に限定していれば神経障害を生じることは非常に稀 で，自験例では $0.5 \%$ 程度であった。 しかも，その条件 下で生じる神経障害は鵎卵大の知覚鈍麻を伴うだけで数 カ月で改善し, 合併症としては軽微なものと言える。た だし，何らかの理由で伏在神経や腓腹神経を傷害する と, 長期間に渡って知覚鈍麻に加えて異常な知覚による 不快感が伴われるため様相は大きく異なる，対策は非 常にシンプルで, とくに伏在神経や腓腹神経が走行して いる部位では脂肪深層にフックを入れないことにつき る，そして，麻酔を浅くすることも重要で，筆者も何度 かフックで神経に触れているが，麻酔が浅かったことに
よって患者より痛みの訴えがあり，それ以上のダメージ を避けることができた。

血栓性静脈炎：言うまでもなく血栓性静脈炎は静脈 のない部位には生じない。よって，SAによって予定し た部位の血管が十分に摘出された場合には生じることが なく，むしろ静脈を取り残したところに血栓・炎症を生 じることとなる。したがって，血管が脆い症例や周囲と の癒着が強い症例では，稀に残存瘤に血栓性静脈炎を生 じる例があるが，臨床的に問題となることはほとんどな い. むしろ, 血管内焼灼術で焼灼された伏在静脈（とく に浅在化している場合）に血栓性静脈炎を生じる可能性 の方が高く，これは対処を必要とすることが多い.

感染：SAに直接関連する創感染はほとんど経験した ことがない．膿を伴うような創感染を生じた場合は何か 別の原因を疑ったほうが良いと思われる。

その他：リンパ漏を生じることもある。拉そらく視 界に入らない皮下でリンパ管を損傷しているものと思わ れる，指先の感覚を研き澄まし，血管と感触の異なるも のはむやみに引っ張らないようにすることで損傷を避け ることができる.

\section{最 後に}

血管内焼灼術の登場により，日帰りでの下肢静脈瘤 治療が主体となりつつある中で，わずかではあるが出 血・疼痛などの原因になりうるSAの併用をためらって いる施設も多いと思われる。しかし，いくつかの注意点 さえ忘れなければ，SAは非常に低侵襲かつ治療効果の 高い術式であり，積極的に併施するべきだと考える．本 稿がSA導入への一助となれば幸いである.

\section{利益相反}

利益相反はない.

$$
\text { 付 記 }
$$

日本静脈学会（2017年 徳島）にて発表.

\section{文献}

1) Schanzer H: Endovenous ablation plus microphlebectomy/sclerotherapy for the treatment of varicose veins: single or two-stage procedure? Vasc Endovascular Surg 2010; 44: 545-549

2) Monahan D: Can phlebectomy be deferred in the treatment of varicose veins? J Vasc Surg 2005; 42: 1145-1149

3) Carradice D, Mekako AI, Hatfield J, et al: Randomized clinical trial of concomitant or sequential phlebectomy after endovenous laser therapy for varicose veins. Br J Surg 2009; 96: 369-375

4) El-Sheikha J, Nandhra S, Carradice D, et al: Clinical outcomes and 
quality of life 5 years after a randomized trial of concomitant or sequential phlebectomy following endovenous laser ablation for varicose veins. Br J Surg 2014; 101: 1093-1097

5) Pittaluga $P$, Chastanet $S$ : Persistent incompetent truncal veins should not be treated immediately. Phlebology 2015; 30 Suppl: 98-106

6) 佐戸川弘之, 杉山 悟, 広川雅之, 他：下肢静脈瘤に対する血管 内治療のガイドライン。静脈学 2010; 21: 289-309

7) Klein JA: The tumescent technique for liposuction surgery. J Am
Acad Cosmetic Surg 1987; 4: 263-267

8) Klein JA, Jeske DR: Estimated maximal safe dosages of tumescent Lidocaine. Anesth Analg 2016; 122: 1350-1359

9) Böni R: Tumescent liposuction: efficacy of a lower lidocaine dose (400 mg/l). Dermatology 2010; 220: 223-225

10) Dumantepe M, Uyar I: Comparing cold and warm tumescent anesthesia for pain perception during and after the endovenous laser ablation procedure with $1470 \mathrm{~nm}$ diode laser. Phlebology 2015; 30: 45-51

\title{
Abstract \\ Stab Avulsion up to Date
}

\author{
Takashi Yamamoto
}

Ochanomizu vein \& vascular clinic

Key words: varicose veins, stab avulsion, phlebectomy

Stab avulsion is an operative procedure for the tributary veins of varicose veins that is performed not only to improve the cosmetic result, but also to improve the symptoms and long-term result of the surgery, such as the recurrence rate and the frequency of the need for second-stage procedure. In this article, the operative process of stab avulsion is explained in detail. First of all, large amount of anesthetic solution, which mostly consists of saline with $0.1 \%$ lidocaine, is infiltrated around the preoperatively targeted vein. Then, an incision is made with an 18-gage needle or a common number 11 scalpel which are ideal tools for making $2 \mathrm{~mm}$ incision. A hook is inserted from the incision and the targeted vein is identified by being put between the hook and the fingers. After hooking the vein, it is separated from the surrounding tissue by shaking not the vein but the surrounding tissue gently. And the separated vein is easily exposed out of the incision. The exposed vein is hold with forceps. After looking over the direction and the branches of the vein, the vein is taken out not by pulling the vein but by shaking the surrounding tissue. There are few and slight complications which are directly concerned with stab avulsion, such as bleeding, nerve disturbance, infection and so on.

Jpn J Phlebol 2017; 28(3): 329-335 